\title{
The Development of Tourism-Aware Curriculum Based On the Cultural Values in Madura
}

\author{
Suryo Tri Saksono, Sulaiman, Chairul Anam, \\ and Mujtahidin
}

\begin{abstract}
The purpose of this research is to analyze Madurese's cultural values that will be served as the basic framework and content of tourism-aware curriculum development which can be implemented at school. This research uses research and development approach. The results show: first; Madura's value system is very strong with religious and magic nuance. The Madurese's cultural value which is as the resources and content (core values) of the development of a tourism-aware curriculum model in Madura consists of eight elements: religious, politeness, mutual cooperation, cleanliness, creativity, social awareness, hospitality, and environment-friendly. Second; The main factor in the development of tourism-aware curriculum in Madura is Kiai as a religious figure who is considered by the Madurese as symbols who play a role in maintaining a system of cultural values in Madurese's people. Third; The target of developing tourism in Madura through tourismaware curriculum development is to emerge the 'Five Madura Enchantment' (Lèma' PesonaMadhurâ): clean, peaceful, ordered, islamic, and memorable. Fourth; There would be a guidance book of tourism-aware curriculum which is 'very appropriate' to be used as teacher's guidance in deciding development model and material for discussion of tourism-aware curriculum at school.
\end{abstract}

Key words: cultural value, Kiai, religion, curriculum and tourism, Madura. 


\title{
Rozvoj výukových programů pro cestovní ruch založených na kulturních hodnotách v Maduře
}

\begin{abstract}
Abstrakt
Cílem tohoto výzkumu je analyzovat kulturní hodnoty Madury, které budou sloužit jako základní rámec a obsah rozvoje učebních osnov, které mohou být realizovány ve škole. Tento výzkum využívá přístup výzkumu rozvoje. Výsledky ukazují: Madurský hodnotový systém je velmi silný s náboženskou a magickou nuancí. Madurská kulturní hodnota, která je zdrojem a obsahem (základními hodnotami) vývoje modelu učebních osnov v Maduře, se skládá z osmi elementů: náboženství, zdvořilost, vzájemná spolupráce, čistota, tvořivost, sociální povědomí, pohostinnost a přátelství k životnímu prostředí. Hlavním faktorem vývoje učebních osnov v Maduře je Kiai jako náboženská osobnost, kterou Maduřané považují za symboly, které hrají roli při udržování systému kulturních hodnot v Madurském lidu. Cílem rozvoje cestovního ruchu v Maduře prostřednictvím vývoje učebních plánů, které si uvědomují cestovní ruch, je objevit „Pět kouzel Madury“ (Lèma' PesonaMadhurâ): čisté, pokojné, uspořádané, islámské a památné. Byla by vypracována příručka o učebních osnovách, která by byla „velmi vhodná“ jako učitelský návod při rozhodování o modelu rozvoje a materiálu pro diskusi o učebních osnovách uvědomujících si cestovní ruch ve škole.
\end{abstract}

Klíčová slova: kulturní hodnota, Kiai, náboženství, kurikulum a turismus, Madura.

\section{Introduction}

The modern era of globalization demands the availability of high quality human resources in responding to the advance of science and technology and in an effort to adapt to the structural transformation in the field of manpower.Comparative excellece alone will not be enough to compete in the global arena without the support of human resource excellence. The development in the field of education should be directed into efforts to raise public awareness about tourism development in Madura, particularly through the school curriculum. This is because of the amount of tourism potential that can be a capital acceleration of development in Madura, however it is not in line with the development through education and learning programs at schools. One of the functions of education is for the inheritance of cultural values (including local cultural values) that can be used as a guide in good social life and develop themselves in society. Therefore, in order to have development in Madura running and working well, it must be harmonized with the value system that developed in the society. A positive thing and growing system of values, ethics and culture in society needs to be explored so 
that it can serve as a guide in developing development priorities (both in education and in tourism) in Madura.

The results of Focused Group Discussion (FGD) Education of Science Techno Park (STP) at the University of Trunojoto Madura (UTM) with stakeholders and related institutions in Madura recommends the need for education development efforts in Madura aimed at raising awareness, participation, and community preparedness more specifically the members of the school) about the development of tourism in Madura. Based on the report of Education of STP (Saputro, 2015), several issues of education development based on identification of mapping problems and education development priorities in Madura are: (1) index of Madurese human development is still low, (2) openness to community change is still low, (3) the instrument of tourism development planning in Madura is still weak, especially in the school curriculum, and (4) the unavailability of tourism-aware curriculum in educational institution (school), either in the form of self-development curriculum (life skill and entrepreneurship), as well as local content curriculum.

The development planning that has space from the life and social setting of Madurese, will not only cause alienation, therapy will also lead to disconnected continuity and alignment, which eventually Madura island will be difficult to catch up with the other areas of development. Characteristics of the Madurese are to have a high work ethic and a strong and deeply rooted (religious) community value system. These characteristics are balanced with the potential of natural resources in the form of tourism destinations in Madura which is wide and very diverse.

The purpose of this study is to analyze the cultural values of the Madurese community that will serve as the basic framework and content of tourism-aware curriculum development that can be implemented in schools.

\section{Methods}

This research uses research and development approach. Overall, in accordance with the general purpose of the research, the type of research used is a development study that uses cycles of analysis, design, evaluation, and revision (Plomp, 2010). For research in the first phase in the first year used exploratory study method with the aim of mapping and making analysis of core values system of Madurese which will serve as the basic framework and content development of tourism aware curriculum that can be implemented in educational institutions (schools) in Madura. The types of the data collection in this study include both qualitative and quantitative data. Data collection techniques used are observation, interviews, questionnaires, field notes, document analysis, and image/ video recording. Instruments are developed according to the stages of the study. The research and development stage using the adaptation of the model of development steps 
proposed by Borg and Gall (2007) includes 10 (ten) stages of activity: (1) preliminary study, (2) data analysis, (3) developing research instruments, 4) field studies, (5) floating conceptual models, (6) model validation, (7) model revisions, (8) model trials, (9) model enhancements, and (9) reports and publications. The data obtained were analyzed by qualitative analysis technique with interactive analysis model by: (1) data collection, (2) data reduction, (3) display data, and the last (4) conclusion: drawing and verifying of data and information obtained (Millers and Heberman, 2009). Qualitative data collection uses saturation techniques (data coverage) and triangulation, with the aim of testing whether the proposed model is feasible and can be implemented in schools.

\section{Results and Discussion}

\subsection{Preliminary Study Results}

Madura is an island located in the west of East Sea of East Java. The length of Madura island is about $190 \mathrm{~km}$ and the widest distance from the north coast with the south coast of the island is about $40 \mathrm{~km}$, with it's area about $5.250 \mathrm{~km} 2$ (smaller than Bali Island). Madura administration is divided into 4 (four) districts, namely: Bangkalan, Sampang, Pamekasan, and Sumenep. While politically, Madurese for centuries has became a subordinate of power dominated in Java. Around 900-1500 AD, the island is under the influence of the Hindu Kingdom of East Java such as Kediri, Singosari, and Majapahit (Source). Between 1500 and 1624, Madurese rulers depended on the Islamic empire in the blood of north coast of Java such as Gresik, Demak and Surabaya. In 1624, Madura was conquered by Mataram. In 1882 Madura was in Dutch colonial power, first by the VOC later by the Dutch East Indies. In the 1920s Madura became part of the province of East Java. The tribe of Madura is an ethnic with a large population in Indonesia. The number is now about 20 million inhabitants. They are from the island of Madura and the surrounding small islands. The tribe of Madura is famous for his outspoken style of speech so that the tempramental nature is easily offended. Self-esteem is also important in the life of Madura, they have the proverb 'angok pote tolang, tembot pote mata' which means better to die than to bear shame. Madura value system is very strong with religious and magical nuances, has a character with a hard nature as well as some other calm. Madura can not be separated from Islam, although it is admitted that its inhabitants because of illiteracy and blind religion do not know the true nature of Islamic teachings. His soul is similar to the soul of the Bugis tribe, equally dared to seize the great ocean, pitched in between the waves and waves (Source). This character has given birth to an unyielding and consistent work ethic for an ideal, to build up the economy, to uphold and maintain honor or dignity, and to defend his religion. Not a few of those who (only) have a strong willpower, without a clear set of bikes, but they 
succeed in economics, become great merchants and businessmen. Those who have a career through education, also many adorn the positions to the national level, both in the bureaucracy, politics and Armed Forces and Police. Even among them many who succeed in the academic path become lecturers, researchers, professors to university leaders, and many more stories of successful Madurese in other professions.

Economic success as well as other strategic positions for the Madurese, still boils down to one point ie Islam. The Madurese who succeed anywhere and in any position, remain inseparable with Islam, although many of them are in the level of symbolic acknowledgment, but their Islamic commitment has not faded since Islam entered this island of funds into a choice of Madurese beliefs until now. The persistence of the Madurese community of the Islamic tradition is inseparable from the role of religious figures since Islam entered the island along with the time of the entry of Islam in the archipelago, especially on the island of Java. The early scholars of Islam spread were trusted people because of the height of mind and the knowledge they possessed. His daily life is like a mirror for other members of society, a role model and an almost flawless role model, to gain a glorious place in the midst of his society. Even in its development, the cleric became the central who "defeated" the character of kings, government officials and nobles (Hamka, 1982).

Madurese has assumption that the development of tourism can influence the cultural value system that has been attached to Madurese society. The ethical system embedded in the minds of the Madurese is a strong Islamic or Eastern ethic. Changing the view (mainstraim) of society can not be done as easy as turning the palm of the hand. These changes should be made through the awareness process one of them through the education process. Development in the field of education should be directed at efforts to raise public awareness about tourism development in Madura, especially through the school curriculum. This is because the amount of tourism potential that can be a capital acceleration of development in Madura but not in tune with the development through education and learning programs in schools. As far as research and identification has been done by the Research Team, there is no tourism-aware curriculum in Madura schools, whether developed in the form of local content subjects, integrated in subjects, as well as in self-development activities.

\subsection{Field Study Results}

Culture of Madurese people with religious culture and adhering to their culture and traditions can become one of the trademarks in tourism development in Madura. Tourism awareness curriculum (KSP) as one of the curriculum implementation in schools aims to increase the participation of students and school residents as members of the community in the development of tourism as an empowerment effort so that people can play a more active and optimal role as well as receive positive benefits from development 
activities the field of tourism undertaken for the improvement of his welfare. The empowerment of learners and schoolchildren in the context of tourism development can be understood as an effort to strengthen and improve the capacity, roles and initiatives of school members as community members and stakeholders to participate and play an active role as subject or actor or beneficiary in sustainable tourism development.

This understanding affirms the important position of schools in development activities, namely as 'head' as well as 'tail' in community empowerment. As the 'head' means the school is expected to be a driving force that prepares innovations in various areas of life that benefit the community in the future. While as 'tail' means the changes made by the school always follow and adjust to the needs and characteristics of the community around him. This will bring benefits for the formation of learners who can play a role as a subject or development agent, can also prepare learners with competencies that meet the needs of the community as beneficiaries of development.

School residents as subjects or development actors imply that schools should be important actors who must be actively involved in the process of planning and developing tourism, along with other relevant stakeholders from both the government and the private sector. In its function as a subject or actor, the school has the roles and responsibilities to jointly promote the successful development of tourism in its territory (region) respectively. While the school community as beneficiaries implies that schools can prepare students with a set of competencies in the future that is not just 'spectators' but can become 'actors' of tourism empowerment. Thus, learners are expected to obtain significant economic benefits from the development of tourism activities to improve their quality of life and social welfare in the future.

Implementation of KSP in schools can be a cultivation of character values that support the development of tourism through curriculum and school culture in Madura. The cultural values of Madurese society which are the basic values and the value of the needs that are the core values in the development of the tourism conscious curriculum are eight: religion, politeness, mutual assistance, hygiene, creativity, social concern, hospitality and environmental care. The target of KSP development and implementation in schools is to establish learners' awareness about the importance of realizing tourism development in Madura. This targets are expected to lead to: (1) increased interest in tourist visits to tourism destinations in Madura, (2) growth of prospective tourism business climate, and (3) increased employment and income opportunities and economic impacts for Madurese. This effort is done through the formation of the character of learners in creating a conducive and ideal environment for the development of tourism in Madura through Panca Pesona Madura (Lèma' Pesona Madhurâ). Panca Pesona Madura means five Madura charms that become the ideals and targets of tourism development that can attract tourists to visit Madura. Panca Pesona Madura is poured in the jargon "BATIK MADURA" which became the target of the tourism conscious formation in Madura, they are: Bersih (Clean), Aman (Safe), Tertib (Orderly), Islami (Islamic), and Kenangan (Memories). 
- Clean is an environmental condition that displays a healthy atmosphere, comfortable, free of dirt, waste, disease, and pollution. If the tourist spot is clean, will certainly make tourists feel at home to enjoy it, because tourists will feel at home and comfortable when in clean and healthy places.

- Safe is a condition where tourists feel happy to visit a place or a tourist attraction because they feel safe, not afraid, peaceful, and protected. The sense of security is very beneficial to the attraction of tourists so that there is no fear of traveling, the desire to visit will be greater, and the positive image of tourism will also be maintained, as well as opportunities for development and improvement of facilities and useful service and information systems both in places of attractions and in other places will become more open. This will have an impact for the emergence of tourist attraction to the island of Madura.

- Orderly is a condition that reflects an orderly, neat and smooth atmosphere and shows high discipline in all aspects of people's lives. The benefits of the realization of an orderly atmosphere is the creation of calm, orderly conditions, the formation of dignity as a cultured society in accordance with the cultural values of Madurese society.

- Islami means Islamic or Islamic morals. Religion for the people of Madura is synonymous with Islam, because Islam has permeated and colored their social life patterns, and religion is considered a sacred thing to be defended and implemented in all the joints of life. Islamic refers to the conditions of tourism development by considering the basic values of Muslims in the presentation, ranging from accommodation, restaurant, to tourism activities that always refer to the norms of Islam.

- Memories are memories or positive impressions that are stored or attached to and strong in the memory/ mind of a person caused by experience gained. Memories can be something beautiful (fun) or unpleasant memories. The development of tourism in Madura is expected to create beautiful (pleasant) memories in the memories and the feeling of tourists from the experience of traveling in Madura. Beautiful memories will benefit the formation of respect and appreciation from others, the formation of a good image for the person and society of Madura, the creation of satisfaction for both yourself and for every visitor (tourists) who will come to Madura, and can increase the mutual trust among others.

\subsection{KSP Implementation Model at School}

The main factor in the development of The tourism-aware curriculum in Madura is Kiai as a religious figure who is considered to play a role in maintaining the cultural value system in society. That is, the development of tourism in Madura needs to get support from the figure of Kiai. Investors and the private sector can contribute in the development of tourism in Madura, but must get support and approval from Kiai first. This 
factor is always a very important factor to the attention of the investors, private, and government. Tourism potential that can be developed into a tourism-aware curriculum is cultural tourism and religious tourism. The tourism-aware curriculum implementation using the concept of cultural tourism development and religion is expected to be one of the 'entrance' in order to prepare the instrument of tourism development in Madura through the school curriculum. In the future, it is expected that the development of nature tourism (beach) will also be developed more prospectively.

- The core values which are the basic values and the value of needs in realizing the Panca Pesona Madura through 'BATIK MADURA' in the development of The tourismaware curriculum consist of religious values, modesty (polite), mutual cooperation, maintaining cleanliness, creativity, social, hospitality, and caring environment. KSP can be implemented through local content subjects, through personality development subjects (Religion Education, Civics, Social Studies, and Cultural Arts), and through self-development and entrepreneurship activities.

- The tourism-aware curriculum models through local content subjects are implemented through special subjects in local content subjects. The local content is the study material in the educational unit containing the content and learning process about the local potential and uniqueness that is intended to shape the learners' understanding of the potential in the area where they live.

- The tourism-aware curriculum model through personality development subjects (Religion Education, Civics, Social Studies, and Cultural Arts) implemented using integrated approach to the subjects and integrated development pattern that is by linking Basic Competence subjects with study materials contained in the tourismaware curriculum

- The tourism-aware curriculum model through self-development activities and entrepreneurship is done through self-development activities by integrating the tourism-aware curriculum study materials in extracurricular activities. This model is implemented using a holistic and humanistic approach by providing opportunities for learners to develop and express themselves according to the needs, talents, and interests of each learner in accordance with school conditions. Self-development is done through extracurricular activities such as scouting, leadership, youth scientific groups, and career guidance. While entrepreneurship can be done through training expressing entrepreneurial ideas, choosing entrepreneurial activities, and preparing business plans.

\subsection{Implementation of The Tourism-Aware Curriculum at School}

Implementation of KSP in schools can be implemented with the following provisions (1) The tourism-aware curriculum can be implemented as a separate subject in the form of local content subjects. (2) The tourism-aware curriculum as a special subject 
of local content, the time allocation is 2 hours/ week. (3) The tourism-aware curriculum as special subject matter of local content carried out for one semester or one year. Thereafter, the tourism-aware curriculum implementation can be evaluated in 3 years. (4) The tourism-aware curriculum learning assessment as a special subject of local content prioritizes performance, product, and portfolio. (5) If not as a separate subject, the tourism-aware curriculum study materials can be integrated into other subjects (Religion Education, Social Studies, Civics and Cultural Arts). (6) The tourism-aware curriculum study materials can be developed in entrepreneurship learning in schools. (7) The tourism-aware curriculum study materials can be implemented through selfdevelopment activities (extracurricular activities) in schools, such as Boy Scouts. (8) The tourism-aware curriculum can be implemented through school habituation and culture activities such as culture of good attitude and behavior, displaying slogans, examples, and some positive habituation activities for learners. (8) The tourism-aware curriculum can be taught at every level ranging from primary and secondary education level.

\subsection{The contents of the the tourism-aware curriculum}

Content include the following development outcomes: Madura tourism industry, Madura tour guide, Madura tourism promotion, Madura regional crafts, Madurese language, Madurese history, traditional ceremonies, Madurese folk games, traditional Madurese sloths and tunes, traditional music, Madura performing arts, Madurese specialties, as well as knowledge of Madurese nature and natural environment. Based on the results of the research, the The tourism-aware curriculum development guidebook was obtained with the criteria 'very feasible', which can be used as a guide for teachers in determining development model and the tourism-aware curriculum study materials in schools. This tourism-aware curriculum development guide book can be used as a guideline for teachers and schools in preparing the basic framework and content of the tourismaware curriculum development either through special local content subjects as well as integrated through personality development and self development activities in schools.

\section{Conclusion}

Madura value system is very strong with religious and magical nuances, has a character with a hard nature as well as some other calm. If they (Madurese) are placed in a clear position, not disturbed, treat them fairly, then they will be good to anyone even though they are new to him. The cultural values of Madurese society which are the basic values and values that are core values in the development of tourism-aware curriculum consist of eight, namely: religious, modesty, mutual assistance, maintaining hygiene, creativity, social caring, value of hospitality, environmental caring value. The 
main factor in the development of the tourism-aware curriculum in Madura is Kiai as a religious figure who is considered to play a role in inheriting and maintaining a strong cultural value system inherent in community life. The target of tourism development in Madura through the development of the tourism-aware curriculum in schools is the realization of 'Panca Pesona Madura' (Lèma' Pesona Madhurâ) which is poured in the jargon of "BATIK MADURA" namely: Bersih (Clean), Aman (Safe), Tertib (Orderly), Islami (Islamic), and Kenangan (Memories). The tourism-aware curriculum development needs to be implemented in curriculum development and learning at educational institutions in Madura, from elementary education to secondary education. The tourism-aware curriculum development guidebook obtained based on the results of this study has met the criteria 'very feasible' and can be used as a guide for teachers and schools in preparing the basic framework and content of the tourism-aware curriculum development in schools.

Steps and efforts are required to develop, implement and cultivate the the tourismaware curriculum effectively and consistently through the school curriculum. Therefore, the participation of all parties, both schoolchildren, together with the government and relevant stakeholders to actively engage in the development of tourism awareness through curriculum and school culture in Madura. The tourism-aware curriculum manuals need to be complemented by the tourism-aware curriculum development guidelines either through special subjects or integrated in other subjects. Therefore, in the next stage it is necessary to study and prepare the The tourism-aware curriculum development guidebook for teachers (school) in the form of (1) The tourism-aware curriculum development guidance through local content subjects, (2) The tourism-aware curriculum development guidance through self development and entrepreneurship activities, (3) (model) syllabus and learning implementation plan of The tourism-aware curriculum through local content and entrepreneurship subjects.

\section{Reference}

Akhmad, Bindara. 2002. Lintasan Sejarah Sumenep dan Asta Tinggi Beserta Tokoh Didalamnya. Barokah: Tanpa Kota

Akhyat, Arif, dkk. 2010. Ensiklopedi Pamekasan: Alam, Masyarakat, dan Budaya. Pemerintah Kabupaten Pamekasan bekerjasama dengan Fakultas Ilmu Budaya Universitas Gadjah Mada: Yogyakarta.

Aliv, Rachmatoel. 2015. "Sulur Pesisir: Mengintip Keindahan Seni Ukir Kayu Madura". Dokumen Tidak Diterbitkan.

Badan Penelitiandan Pengembangan Daerah Kabupaten Pamekasan. 2013. “Kerapan Sapi: Budaya, Hukum, dan Pariwisata". Dokumen Tidak Diterbitkan.

BAPPEDA Kabupaten Sumenep, Pusat Pemanfaatan Sains Atmosfirdanlklimdan Lembaga Penerbangandan Antariksa Nasional. 2006. Penelitian Kondisi Lingkungan Pulau Gililyangsebagai Potensi Kawasan Wisata Kesehatan. Sumenep-Indonesia. 
BBTKLPP Surabaya, 2013. Laporan Kajian Kualitas Lingkungandan Faktor Risiko Kesehatan di Kawasan Wisata Giliyang Kabupaten Sumenep Tanggal 1-3 Mei 2013. Surabaya-Indonesia

Borg, W. R and Gall, M. D. 2007. Educational Reasearch: An Introduction (4th Edition). Longman: New York-USA

DisporabudPamekasan. 2009. "Telaah Sumber Sejarah Pamekasandalam Usianya yang Ke-479 (1530-2009)". Dokumen Tidak Diterbitkan.

http://terjemahan.madura.web.id/

Imron, Fuad Amin. 2014. Syaikhona Kholil Bangkalan, Penentu Berdirinya Nahdlatul Ulama. Khalista: Surabaya

Jonge, Huub de. 2011. Garam, Kekerasan, dan AduanSapi: Esai-esaitentang Orang Madura dan Kebudayaan Madura. LkiS: Yogyakara

Mien, A. Rifa'i. 2007. Manusia Madura: Pembawaan, Perilaku, EtosKerja, PenampilandanPandanganHidupnyaSepertiDicitrakanPribahasanya. Pilar Media: Yogyakarta

Miles, M. B danHuberman, A. M. 2009. Analisis Data Kualitatif: BukuSumbertentangMetode-MetodeBaru. DiterjemahkanolehTjejepRohendiRohidi. UI Press:Jakarta

Nurhayati, Alfisah. 2010. "Revisiting Pariwisata Madura; StudiKebijakan Pembangunan Kepariwistaan Kabupaten Sampang". Jurnal Karsa. XVIII (2)

Pendit, N. S. 1999. Ilmu Pariwisata: Sebuah Pengantar Perdana. Pradnya Paramita: Jakarta

Peraturan Menteri Pariwisata Republik Indonesia Nomor 14 Tahun 2016 tentang Pedoman Destinasi Pariwisata Berkelanjutan

Peraturan Pemerintah Republik Indonesia Nomor 50 Tahun 2011 Tentang Rencanalnduk Pembangunan Kepariwisataan NasionalTahun 2010-2025

Plomp, Tjeerd. 2010. Educational Design Research: an Introduction. In TjeerdPlomp and Nienke Nieveen (Ed). An Introduction to Educational Design Research (9-36). Netzodruk, Enschede an. Netherlands

Rani, Deddy PM. 2014. “Pengembangan Potensi Pariwisata Kabupaten Sumenep, Madura, Jawa Timur (Studi Kasus: PantaiLombang)". Jurnal Politik Muda. 3 (3): 412-421.

RPJMD Provinsi Jawa Timur, Tahun 2015-2019

Sadik, A. Sulaiman. 1996. "Madura dalam Sebuah Potret". Dokumen Tidak Diterbitkan.

Saputro, Sigit Dwidkk. 2015. Peta Permasalahandan Prioritas Pembangunan Pendidikan di Madura. STP Pendidikan Universitas Trunojoyo Madura: Bangkalan

Spillane, James J. 1994. Pariwisata Indonesia: Siasat Ekonomidan Rekayasa Kebudayaan. Kanisius: Yogyakarta

Tim Peneliti Sejarah. Tanpa Tahun. "Pamekasandalam Sejarah”. Dokumen Tidak Diterbitkan.

Wahab, Salah. 2003. Manajemen Kepariwisataan. Pradnya Paramita: Jakarta.

\section{Contact:}

Suryo Tri Saksono, Sulaiman, Chairul Anam, and Mujtahidin

English Study Program, Faculty of Social and Cultural Sciences,

University of Trunojoyo Madura, Bangkalan, Indonesia,

e-mail: suryo.saksono@trunojoyo.ac.id 